\title{
Precursory seismicity associated with frequent, large ice avalanches on Iliamna volcano, Alaska, USA
}

\author{
Jacqueline CAPLAN-AUERBACH, ${ }^{1}$ Christian HUGGEL ${ }^{2}$ \\ ${ }^{1}$ Geology Department, Western Washington University, 516 High Street, Bellingham, Washington 98225-9080, USA \\ E-mail: jackie@geol.wwu.edu \\ ${ }^{2}$ Department of Geography, University of Zürich-Irchel, Winterthurerstrasse 190, CH-8057 Zürich, Switzerland
}

\begin{abstract}
Since 1994, at least six major (volume $>10^{6} \mathrm{~m}^{3}$ ) ice and rock avalanches have occurred on Iliamna volcano, Alaska, USA. Each of the avalanches was preceded by up to 2 hours of seismicity believed to represent the initial stages of failure. Each seismic sequence begins with a series of repeating earthquakes thought to represent slip on an ice-rock interface, or between layers of ice. This stage is followed by a prolonged period of continuous ground-shaking that reflects constant slip accommodated by deformation at the glacier base. Finally the glacier fails in a large avalanche. Some of the events appear to have entrained large amounts of rock, while others comprise mostly snow and ice. Several avalanches initiated from the same source region, suggesting that this part of the volcano is particularly susceptible to failure, possibly due to the presence of nearby fumaroles. Although thermal conditions at the time of failure are not well constrained, it is likely that geothermal energy causes melting at the glacier base, promoting slip and culminating in failure. The frequent nature and predictable failure sequence of Iliamna avalanches makes the volcano an excellent laboratory for the study of ice avalanches. The prolonged nature of the seismic signal suggests that warning may one day be given for similar events occurring in populated regions.
\end{abstract}

\section{INTRODUCTION}

Ice avalanches are rare but hazardous phenomena, with the potential to cause enormous damage to mountain communities (Huggel and others, 2004; Kääb and others, 2005). While some events, such as the 1970 Huascarán (Peru) avalanche (Plafker and Erickson, 1978) or a series of ice avalanches in the Kunlan Shan region of Tibet (Van der Woerd and others, 2004) were triggered by major earthquakes, others, including the 2002 icefall and glacial avalanche in North Ossetia, Russian Caucasus (Huggel and others, 2005), have no obvious trigger. The remote setting of many avalanche-prone regions and the fact that such events are not easily predicted means that our understanding of these phenomena can only slowly progress.

A significant contribution to our current understanding of ice avalanches has been made by studies in the European Alps, since the dense population in these mountain areas results in a high vulnerability to ice avalanche hazards (e.g. Alean, 1985; Haeberli and others, 1989; Margreth and Funk, 1999). Conditions of avalanche formation (Alean, 1985; Röthlisberger, 1987; Huggel and others, 2004), dynamics and reach (Alean, 1985; Margreth and Funk, 1999) have been investigated and simple models applied (Salzmann and others, 2004). However, the understanding of many important processes remains limited. Studies concerned with different aspects of ice avalanche processes are therefore needed to better assess related hazards in the future. In fact, recent slope instabilities and ice avalanches on Monte Rosa, Italy, or in the Caucasus indicate that atmospheric warming, glacier shrinkage, permafrost degradation, and destabilization of steep glaciers and mountain walls might increase the hazards from ice avalanches (Haeberli, 2005; Kääb and others, 2005).

The low occurrence rate, remote setting and sudden occurrence of ice avalanches mean that observations and recordings of such events are rare. However, an ideal location for the study of these events exists on Iliamna volcano, Alaska, USA. At least eight large (on the order of millions of $\mathrm{m}^{3}$ ) ice and rock avalanches have occurred on Iliamna since 1994 (Table 1). Six of these events, as well as hundreds of smaller avalanches, were captured on seismic records. As Iliamna is not located near a population center, it is not easily observed, and since routine seismic processing is primarily focused on monitoring of volcanic activity, other smaller avalanches may have gone unnoticed during that time. The high frequency of avalanches and the presence of a local real-time seismic network make lliamna an ideal field laboratory for the study of ice avalanche dynamics and related processes. The data presented here may be used to constrain ice avalanche models and compare avalanching on Iliamna to activity in other regions. Of particular note is the fact that Iliamna ice avalanches exhibit a characteristic seismic sequence including a prolonged precursory phase. Analysis of the precursory seismicity provides insight into ice avalanche failure and dynamics. Improvement of our understanding of ice avalanche failure and propagation characteristics can be useful for modeling and assessment of corresponding hazards on ice-capped volcanoes in similar but more populated settings (e.g. in the Cascades, North America), or in non-volcanic environments (e.g. the European Alps). The discovery and capture of precursory seismic signals prior to avalanche failure result in a means by which warning could be given prior to large avalanches.

\section{PHYSICAL SETTING OF ILIAMNA VOLCANO}

Iliamna is an andesitic stratovolcano in the Cook Inlet region of Alaska (Fig. 1). At $3053 \mathrm{~m}$, it is among the tallest volcanoes in the Aleutian arc, although Iliamna itself represents a thin veneer over a granitic pluton of Jurassic age (Detterman and Hartsock, 1966). Where the granitic rocks are exposed they are heavily altered by hydrothermal 
Table 1. Characteristics of ice avalanches at Iliamna. Data for events 1-4 from Waythomas and others (2000). Failure elevation is estimated to be accurate to $\sim 100 \mathrm{~m}$ for all avalanches. Initial and entrained volumes are estimated only for avalanches for which we have satellite data (events 5-8). Durations are estimated from the length of the spindle-shaped seismic signal and are estimated to be accurate to $\sim 10-20 \%$. Seismic signals were not identified in association with events 2 and 3, and were identified only in retrospect for event 8

\begin{tabular}{|c|c|c|c|c|c|c|c|c|c|c|c|c|}
\hline \multirow[t]{2}{*}{ Avalanche } & $\begin{array}{l}\text { Failure } \\
\text { elevation }\end{array}$ & $\begin{array}{c}\text { Drop } \\
\text { height } H\end{array}$ & $\begin{array}{l}\text { Runout } \\
\text { length } L\end{array}$ & $H / L$ & $\begin{array}{c}\text { Initial } \\
\text { volume }\end{array}$ & $\begin{array}{l}\text { Volume } \\
\text { entrained }\end{array}$ & $\begin{array}{c}\text { Total } \\
\text { volume }\end{array}$ & $\begin{array}{l}\text { Failure } \\
\text { slope }\end{array}$ & $\begin{array}{l}\text { Avalanche } \\
\text { duration }\end{array}$ & Velocity & $\begin{array}{l}\text { Precursory } \\
\text { seismicity? }\end{array}$ & $\begin{array}{l}\text { Failure } \\
\text { material }\end{array}$ \\
\hline & $\mathrm{m}$ & $\mathrm{m}$ & $\mathrm{m}$ & & $10^{6} \mathrm{~m}^{3}$ & $10^{6} \mathrm{~m}^{3}$ & $10^{6} \mathrm{~m}^{3}$ & ○ & s & $\mathrm{ms}^{-1}$ & & \\
\hline $\begin{array}{l}\text { 1. } 30 \text { Jun. } 1994 \\
\text { Red Glacier }\end{array}$ & 2200 & 1750 & 10000 & 0.18 & & Unknown & 16.5 & 41 & 500 & 20 & Yes & $\begin{array}{l}\text { Ice-rock } \\
\text { interface }\end{array}$ \\
\hline $\begin{array}{l}\text { 2. } 1994 \\
\text { Red Glacier tributary }\end{array}$ & 1900 & 1006 & 3400 & 0.29 & & Unknown & 2.3 & Unknown & & & Unknown & \\
\hline $\begin{array}{ll} & 1994 \\
& \text { Umbrella Glacier }\end{array}$ & 2400 & 1366 & 3000 & 0.45 & & Unknown & 0.97 & $37-40$ & & & Unknown & \\
\hline $\begin{array}{l}\text { 4. } 19 \text { May } 1997 \\
\text { Red Glacier }\end{array}$ & 2200 & 1640 & 7700 & 0.21 & & Unknown & 14 & $38-40$ & 170 & 45 & Yes & $\begin{array}{l}\text { Ice-rock } \\
\text { interface }\end{array}$ \\
\hline $\begin{array}{l}\text { 5. } 25 \text { Jul. } 2003 \\
\text { Red Glacier }\end{array}$ & 2430 & 1940 & 8570 & 0.23 & 6 & $6-14$ & $12-20$ & 41 & 180 & 48 & Yes & $\begin{array}{l}\text { Ice-rock } \\
\text { interface or } \\
\text { within ice }\end{array}$ \\
\hline $\begin{array}{l}\text { 6. } 9 \text { Feb. } 2004 \\
\text { Umbrella Glacier }\end{array}$ & 2400 & 1700 & 6200 & 0.27 & 1 & $1.5-4$ & $2.5-5$ & 37 & 80 & 77 & Yes & Ice \\
\hline $\begin{array}{l}\text { 7. } 8 \text { Sept. } 2004 \\
\text { Umbrella Glacier }\end{array}$ & 2550 & 880 & 1800 & 0.490 & $0.1-0.15$ & Unknown & $0.1-0.15$ & $45-50$ & 40 & 45 & Yes* & $\begin{array}{l}\text { Ice-rock } \\
\text { interface? }\end{array}$ \\
\hline $\begin{array}{l}\text { 8. } 10 \text { Sept. } 2004 \\
\text { Lateral Glacier }\end{array}$ & 2560 & 1750 & 4950 & 0.33 & $2-3$ & $2-3$ & $4-6$ & 40 & 110 & 45 & Yes & $\begin{array}{l}\text { Ice-rock } \\
\text { interface }\end{array}$ \\
\hline
\end{tabular}

*Very weak, identified only in retrospect.

activity and are weakened and friable (Waythomas and others, 2000). Several glaciers mantle Iliamna's flanks, notably Tuxedni Glacier to the north, Lateral Glacier to the northeast, Red Glacier to the east and Umbrella Glacier to the west (Fig. 1). These glaciers have a combined volume of $\sim 15 \mathrm{~km}^{3}$, with $\sim 1 \mathrm{~km}^{3}$ of ice mantling the uppermost $1000 \mathrm{~m}$ of the edifice (Trabant, 1999).

Iliamna's flanks are heavily dissected by avalanches and the effects of glaciation. In particular, the east and west flanks have large $\left(\sim 0.5 \mathrm{~km}^{3}\right)$ amphitheater-like scarps. These features may be glacial cirques, or they may have resulted from Holocene sector collapses, as they truncate young lava flows (Waythomas and others, 2000). Rocks exposed in these scarps appear to have undergone hydrothermal alteration, consistent with the presence of active fumaroles on the east flank and near the summit.

\section{ICE AVALANCHES ON ILIAMNA VOLCANO}

Ice and rock avalanches are common occurrences on Iliamna, with at least eight large (volume on the order of $10^{6} \mathrm{~m}^{3}$ ) events occurring between 1994 and 2005 (Table 1). There are several factors likely to be contributing to the frequency and volume of these events. A primary factor is the large volume of ice available for failure (Trabant, 1999). Furthermore, although the volcano has no confirmed historic eruptions, it has active fumaroles and experienced a dike intrusion in 1996 (Roman and others, 2004). Volcanic unrest could promote ice avalanches by increasing heat flux within the edifice, melting the base of the glacier cover and promoting slip at the glacier base. Furthermore, Iliamna's exposed rock is heavily altered by hydrothermal activity, and is prone to failure (Waythomas and others, 2000). Avalanches may initiate in rock or they may entrain friable rock as they travel. This not only enhances avalanche volume but increases the density of the avalanche material, imposing a larger force upon the ground and thus increasing the amplitude of seismic signals associated with the avalanche.

Terrain data for the description and analysis of the avalanches are based on digital elevation models (DEMs) derived from Advanced Spaceborne Thermal Emission and Reflection Radiometer (ASTER) stereo imagery (acquired 30 October 2004) and Shuttle Radar Topography Mission (SRTM) data (Rabus and others, 2003).

\section{0s and 1980s}

Although not recorded seismically, several high-volume ice avalanches on Iliamna were reported in the 1970s and 1980s. Alean (1984) describes avalanches in 1978, August 1980 and July 1983, all of which descended on Red Glacier. The 1980 event was the largest, with an estimated total volume of $28 \times 10^{6} \mathrm{~m}^{3}$ and a failure volume of $10.8 \times 10^{6} \mathrm{~m}^{3}$ (Alean, 1984). The avalanche initiated from the same location and followed approximately the same path as events in 1994, 1997 and 2003, described below.

\section{June 1994 Red Glacier avalanche}

On 30 June 1994 a large avalanche broke from the eastern flank of Iliamna and traveled a distance of $\sim 10 \mathrm{~km}$ down Red Glacier (Fig. 2a). The avalanche was described by Waythomas and others (2000) as initiating within the hydrothermally altered rock near the head of Red Glacier. A photograph of the failure zone, however, shows a headwall at approximately $2200 \mathrm{~m}$ elevation. A region in which ice has been removed, exposing the underlying rock, can be seen in Figure 2b, suggesting that the avalanche may 


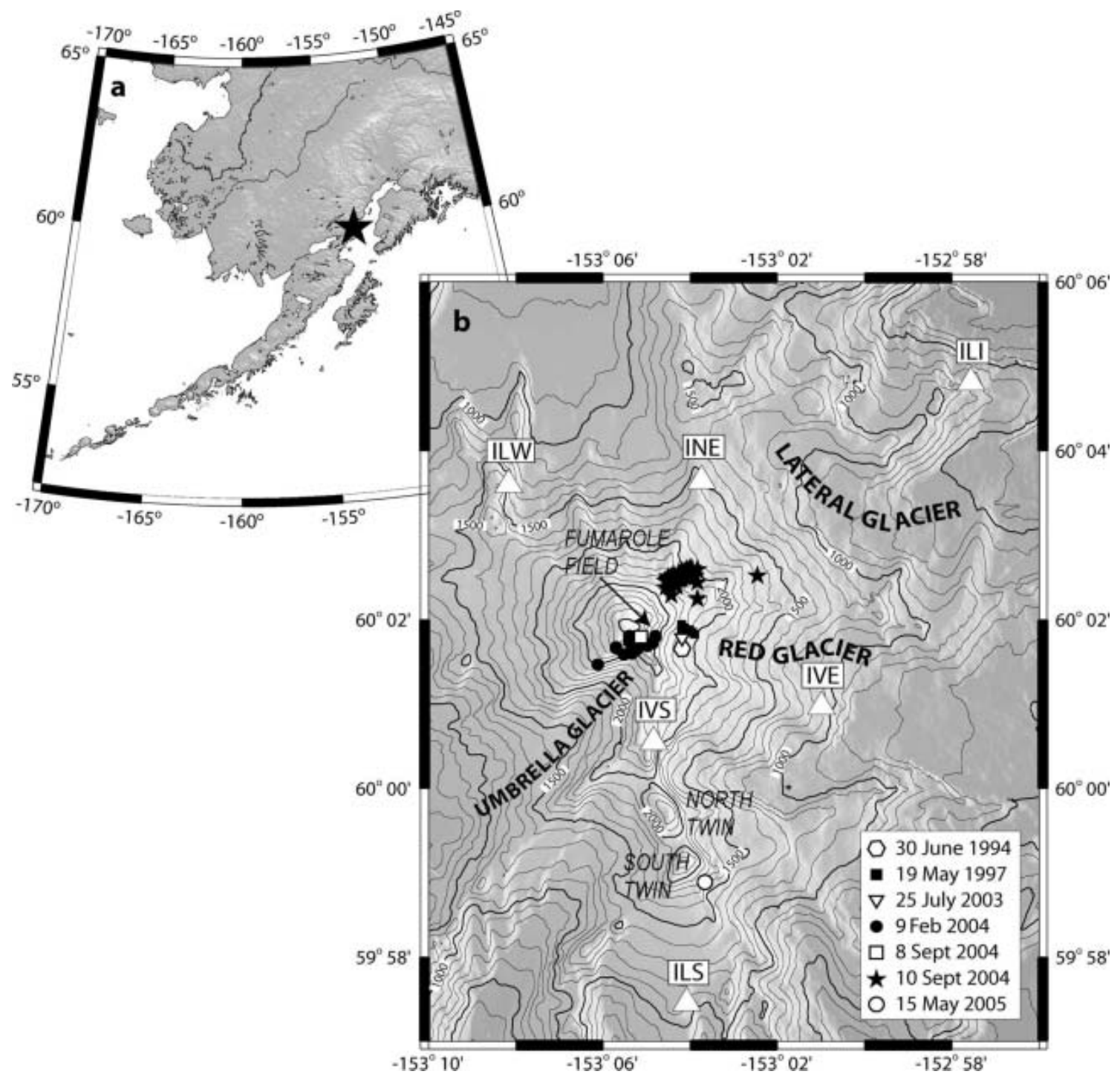

Fig. 1. (a) Location of Iliamna volcano in the Cook Inlet region of Alaska. (b) Epicentral locations of precursory earthquakes plotted for May 1997, February 2004 and 10 September 2004 avalanches; otherwise symbols denote the location of the avalanche headwall, identified on overflights. Locations of short-period seismic stations operated by the Alaska Volcano Observatory are represented by white triangles (ILW, INE, etc.)

have detached from the ice-rock interface. The volume of the avalanche was estimated to be $16.5 \times 10^{6} \mathrm{~m}^{3}$ (Waythomas and others, 2000). The avalanche deposit comprised a mixture of silt, sand and boulders, suggesting either that rock was part of the initial failure, or that the avalanche entrained rock as it propagated. The headwall scarp is composed of ice (Fig. 2b), suggesting that entrainment is a likely means by which the avalanche incorporated rock. Note that two smaller avalanches in 1994 were described by Waythomas and others (2000) and are included in Table 1 but are not further described here. These events were not associated with a seismic signal and can therefore not be directly compared to the others.

\section{May 1997 Red Glacier avalanche}

The May 1997 avalanche closely resembles the event of June 1994 (Waythomas and others, 2000). Like the 1994 avalanche, the 1997 event initiated high on the east flank of Iliamna, near the head of Red Glacier (Fig. 2c). Its runout distance $(\sim 7.7 \mathrm{~km})$ and volume $\left(14 \times 10^{6} \mathrm{~m}^{3}\right)$ are also similar to the earlier event. Examination of the 1997 deposit shows that the avalanche was composed of $~ 50 \%$ ice and snow (Waythomas and others, 2000). The avalanche headwall is virtually identical to that of the 1994 event, with a headwall scarp composed of ice and removal of material to the underlying rock (Fig. 2c).

\section{July 2003 Red Glacier avalanche}

Like the 1994 and 1997 events, the 25 July 2003 avalanche descended the Red Glacier side of Iliamna (Fig. 3). The avalanche was identified based on its seismic signature, but no further observations were made until 1 August, on an unrelated overflight of the volcano. As with the 1994 and 1997 events, the 2003 avalanche originated in the headwall of Red Glacier at about $2200 \mathrm{~m}$ above mean sea level (ma.m.s.l.). Photographs from the 2003 overflight do not give a sufficiently clear picture of the failure zone but suggest that the failure was in rock and ice (Fig. 4). Rock deposits are observed all along the avalanche path, especially in the upper two-thirds, confirming that significant amounts of rock must have been involved. The avalanche traveled several kilometers onto the nearly 


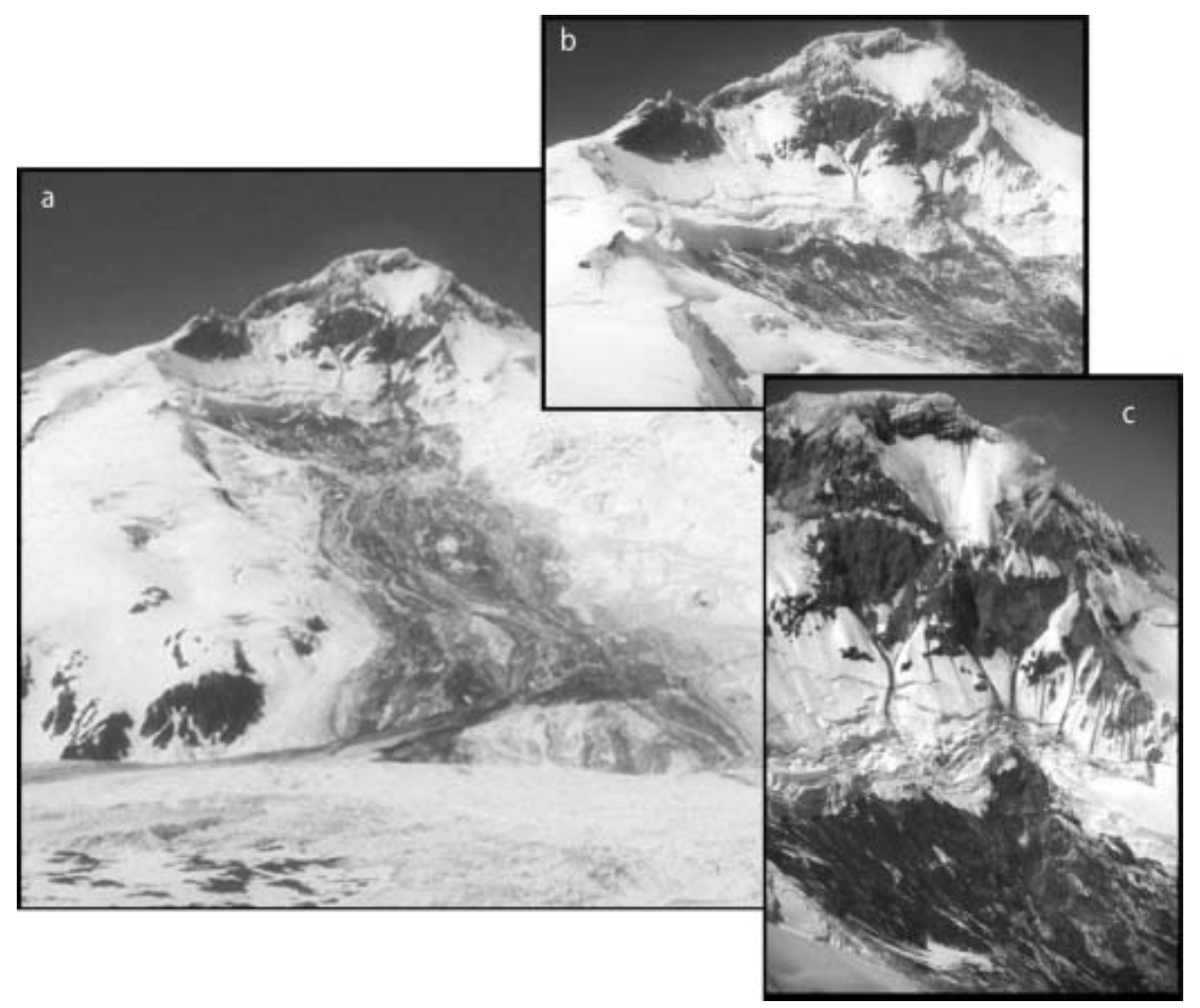

Fig. 2. (a) Eastern flank of Iliamna volcano, showing the 30 June 1994 avalanche route. (b) Close-up of the headwall for the 1994 avalanche. (c) Headwall of the 19 May 1997 avalanche. In (b) and (c), the major fumarole field near Iliamna's summit is visible near the upper right of the photo. In all cases the look angle is to the west. Photographs (a) and (b) courtesy US National Park Service; photograph (c) by V.S. McConnell, courtesy of the Alaska Volcano Observatory, University of Alaska Fairbanks.

horizontal portion of Red Glacier (Fig. 3), an effect of the large initial and entrained volume and probably also due to a high concentration of water.

The apparent headwall of the July 2003 event is similar to that of the 1994 avalanche. Based on photogrammetric studies, the 2003 failure volume is estimated at $6 \times 10^{6} \mathrm{~m}^{3}$, assuming an average failure depth of $15 \mathrm{~m}$. Failure appears to be only partly down to bedrock and only in the uppermost $100-200 \mathrm{~m}$. The total avalanche volume is of the order of the 1994 and 1997 avalanches and is estimated here

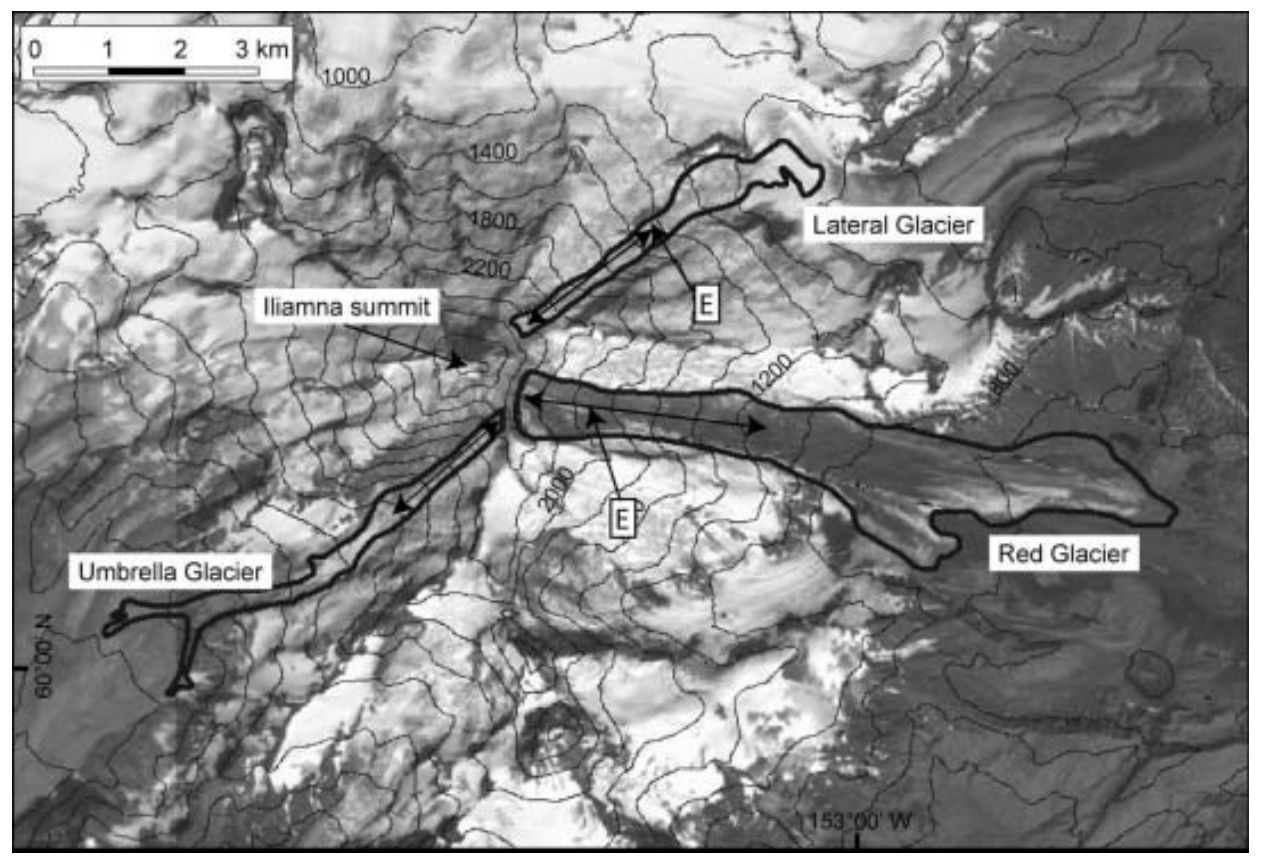

Fig. 3. Outlines of the July 2003 Red Glacier, February 2004 Umbrella Glacier and 10 September 2004 Lateral Glacier avalanches mapped on 9 August 2003 Landsat image. The avalanche outline on Red Glacier is for the July 2003 event, but closely follows the path of the June 1994 and May 1997 avalanches. 


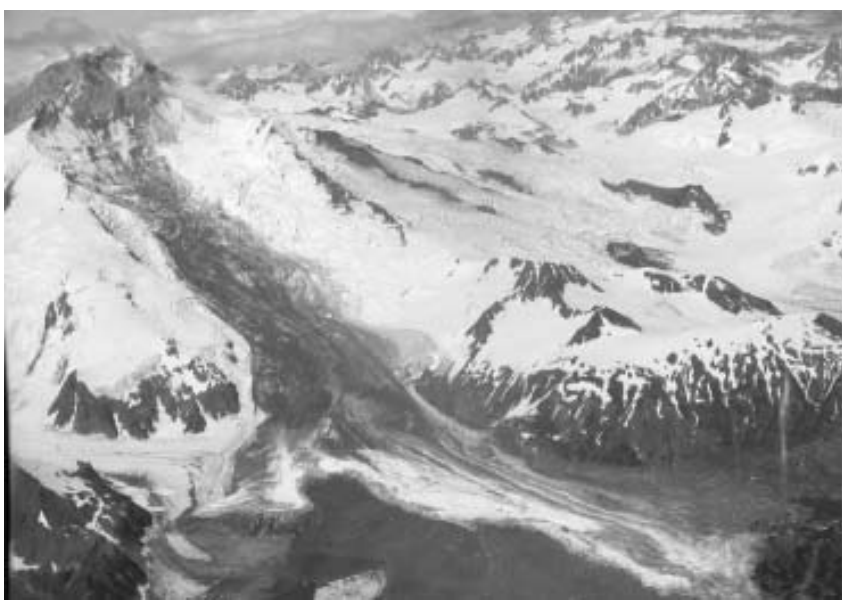

Fig. 4. 25 July 2003 avalanche, illustrating how failure occurred in the same region as the 1994 and 1997 avalanches (Fig. 2). The dark material near the avalanche terminus is partly composed of material from the 1997 debris avalanche (Waythomas and others, 2000). Look angle is to the northwest. Photograph by R. Wessels, US Geological Survey.

as $12-20 \times 10^{6} \mathrm{~m}^{3}$. It should be noted that all the volume estimates contain uncertainties due to a lack of certainty in deposit thickness and entrainment and depositing processes.

Three of the seismically monitored events and three earlier avalanches all initiated from the same region near the top of Red Glacier. In the case of the 1980, 1997 and 2003 events, the flow path and the runout with two distinct flow branches were also quite similar. Furthermore, all avalanches show a strong increase in debris or rock material on the surface starting from about $200-400 \mathrm{~m}$ below the uppermost failure point. This debris may be partly bedrock and partly entrained material. Hence, it appears that Red Glacier avalanches have followed a characteristic pattern in terms of failure, rock entrainment, avalanche dynamics and deposition for at least the past 25 years. This region is a likely candidate for future avalanches.

\section{February 2004 Umbrella Glacier avalanche}

The February 2004 avalanche originated at $\sim 2400 \mathrm{~m}$ elevation above Umbrella Glacier on Iliamna's southwest flank in a zone of strongly hydrothermally altered rock covered by ice (Fig. 3). The travel path of the avalanche was along a massive flank incision, possibly formed by an ancient avalanche (Waythomas and others, 2000). Observation and analysis of the February 2004 avalanche are based on photographs taken during overflights on 18 February and 13 September 2004, as well as high-resolution satellite images and topographic maps.

The failure front of the avalanche was visible on the 18 February photographs (Fig. 5). Unfortunately, the exact boundary of the failure zone is lightly obscured by a dusting of snow. Photographs taken on 13 September reveal that the failure was down to bedrock with an ice thickness varying across the failure zone from about 5 to $20 \mathrm{~m}$ and a slope of $37^{\circ}$. The snowfall also complicated tracking the avalanche path downstream but it was clear that it consisted predominantly, if not exclusively, of ice and snow. As satellite image analysis shows, the avalanche was eroding and depositing snow and ice during downstream flow, a fairly common process for ice-snow avalanches. At
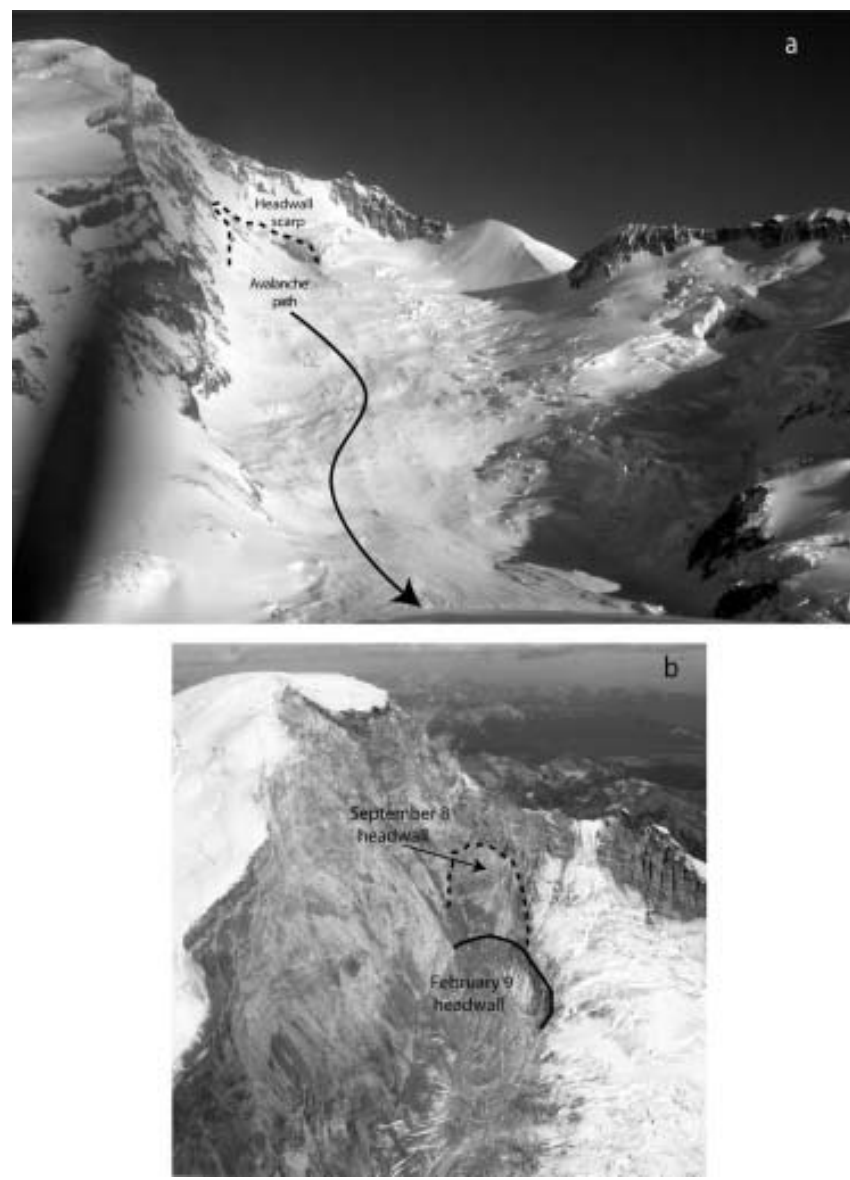

Fig. 5. Source regions for the 9 February 2004 and 8 September 2004 avalanches. (a) Photograph of the 9 February event, taken on 18 February 2004. The avalanche headwall is marked with a dashed line. The avalanche path is covered with a light dusting of snow. There is no snow on the crevassed region on the righthand side of the photo, suggesting that this material was emplaced during the avalanche rather than by snowfall. Photo courtesy M. Hard, US National Park Service. (b) Photo showing the failure region for the 9 February and 8 September events. The headwall for the 8 September event is estimated from regions lacking in snow relative to photos taken in August 2004. Look angles to the northeast. Photo taken 13 September 2004.

about 900 ma.m.s.l. the avalanche split into two branches, resulting in a total maximum runout length of $\sim 6200 \mathrm{~m}$.

The estimate of the February 2004 avalanche volume is only approximate, due to the fresh snowfall and missing deposit thickness measurements. Based on the analysis of the available data and experience with other ice avalanche deposits of similar dimension, the total volume is estimated to be $2.5-5 \times 10^{6} \mathrm{~m}^{3}$ assuming a deposit thickness of $1-2 \mathrm{~m}$ over the whole avalanche trajectory. Based on the geometry of the failure zone, the initial failure likely involved less than $1 \times 10^{6} \mathrm{~m}^{3}$ of ice and snow, thus indicating significant entrainment along the flow path to reach the total avalanche volume estimated.

\section{September 2004 Umbrella Glacier avalanche}

Overflights made on 13 September 2004 revealed further insights into the failure zone of the 9 February 2004 avalanche. This avalanche left the upper glaciated wall debuttressed (Fig. 5b). These observations showed that the entire upper zone of $45-50^{\circ}$ inclination must have failed 


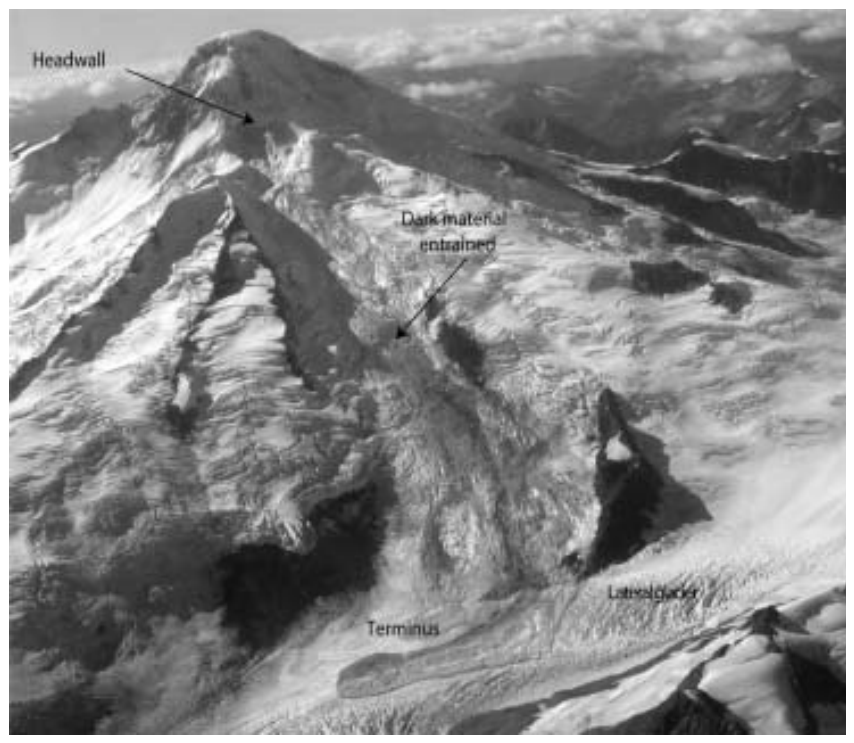

Fig. 6. The 10 September 2004 avalanche, composed primarily of light material (presumably ice and snow) until halfway downslope where dark material appears to be entrained. The avalanche terminus runs partway out onto Lateral Glacier. Look angle is to the west.

subsequent to the February avalanche. It is most likely that this secondary failure occurred in summer when meltwater at the ice-bedrock interface reduced the strength and frictional resistance forces were overcome. A search for seismic recordings of the failure resulted in the identification of a small avalanche signal on 8 September 2004. The avalanche related to this ice failure was significantly smaller than the previous event in February. The failure zone was located at 2550 ma.m.s.l., and the total runout length of the avalanche, although poorly constrained, is estimated to be $\sim 1800 \mathrm{~m}$. The ice thickness of the initial failure was rather small, estimated at $2-3 \mathrm{~m}$. The initial volume might thus be in the order of $100000-150000 \mathrm{~m}^{3}$. Unlike the February avalanche, there was no significant material entrained along the trajectory. Photos of the deposit show talus from subsequent rockfalls in the headwall area.

\section{September 2004 Lateral Glacier avalanche}

A further major avalanche was recorded by the Iliamna seismic network on 10 September 2004 (Fig. 3). The information given here is based on an overflight 3 days after the event, an ASTER satellite image acquired on 30 October 2004 and topographic maps. As the source of the avalanche, the observations identified a large slab failure in the uppermost part of a tributary glacier to Lateral Glacier (Fig. 6). The failure zone is located in the northeastern flank of Iliamna volcano at about 2500 ma.m.s.l. with an inclination of approximately $40^{\circ}$. The overflights clearly showed that the failure was down to the bedrock of the glacier, with two arcuate features marking the initial detachment. The evolution of the arc-shaped cracks could be deduced using photographs from 1 year and 1 month previous to the avalanche. The increasing widening of the cracks with en echelon fractures 1 month before the event and the related displacement of the ice mass below were apparent (Fig. 7). Such failures are also referred to as ramp failures (Haefeli, 1966; Alean, 1985), and are typically related to a reduction in strength at the base of the glacier. The failure depth varies
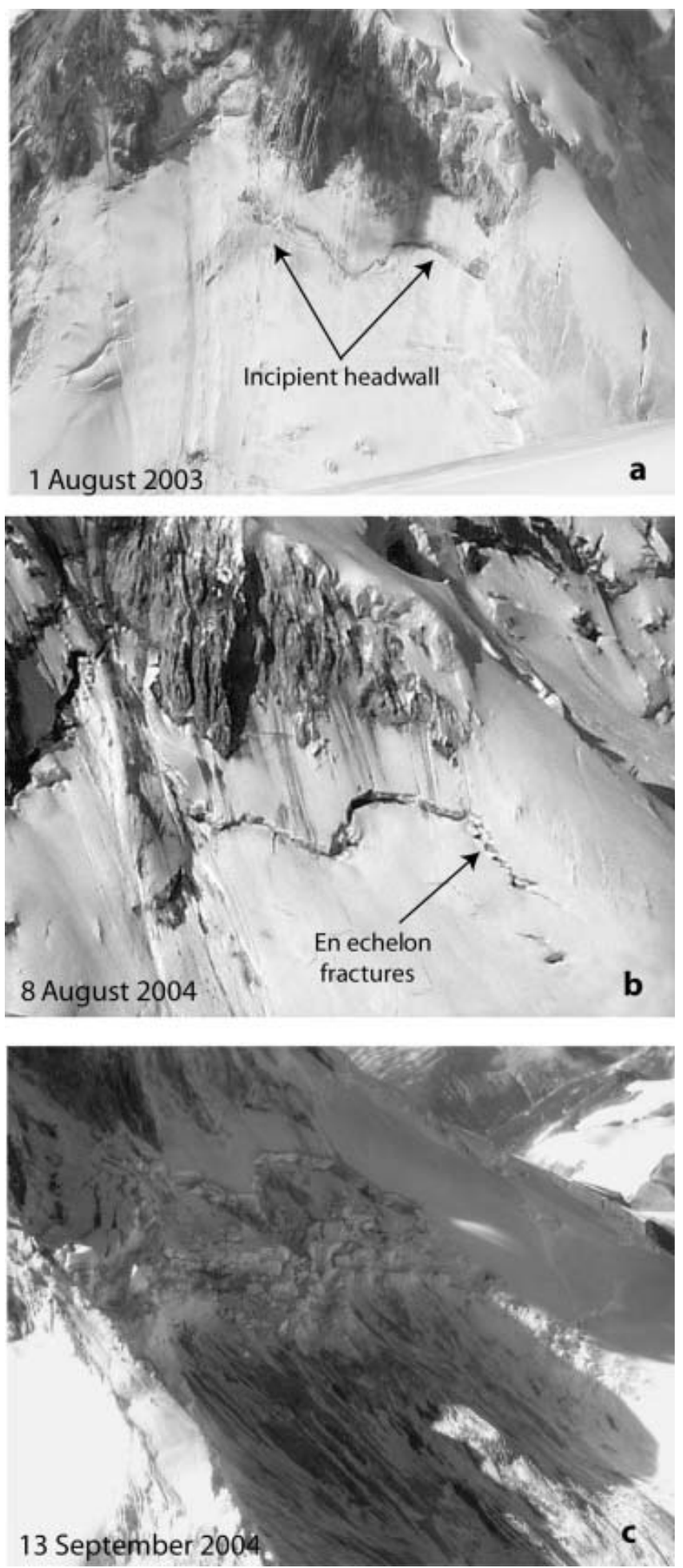

Fig. 7. Stages of failure at the headwall of the 10 September 2004 event. (a) Scalloped crevasse, taken August 2003 by R. Wessels, US Geological Survey. (b) August 2004, when the crevasse has widened. En echelon fractures are visible on the right side of the crevasse. Photograph by M. Doukas, US Geological Survey. (c) 13 September 2004, 3 days after avalanche failure. Ice and snow have clearly been removed to the ice-rock interface.

from about $5 \mathrm{~m}$ in the upper zone to about $30 \mathrm{~m}$ in the lower zone. The initial failure volume is estimated at $2-3 \times 10^{6} \mathrm{~m}^{3}$, and the total avalanche volume at $4-6 \times 10^{6} \mathrm{~m}^{3}$, based on an average thickness over the entire avalanche trajectory of $2-3 \mathrm{~m}$. This results in a bulking factor of $\sim 2$. 


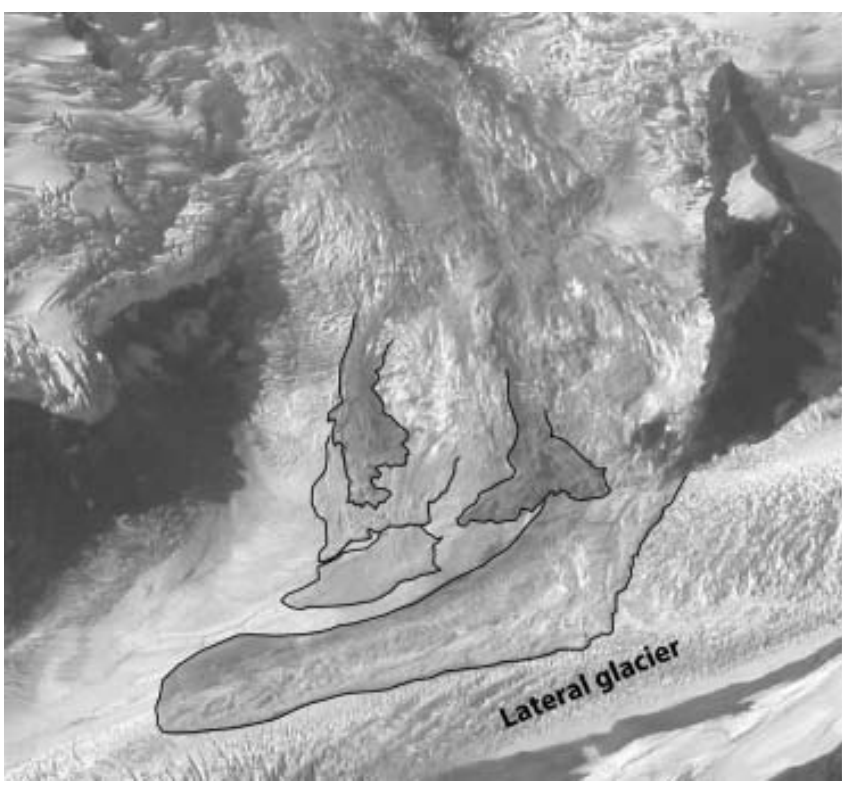

Fig. 8. Debris lobes at the terminus of the 10 September 2004 event. There are several lobes, suggesting that failure occurred in several discrete parts. The earliest failures are lighter in color and appear to have been more fluid than later lobes.

Based on the visual observations, the initial failure was primarily at the ice-rock interface. However, the avalanche deposits suggest that rock was entrained along the trajectory (Fig. 6). The terminal deposits comprise at least four discrete lobes, pointing to different consecutive avalanche flows. The lobes lying on top of earlier deposits are darker than those they overlie, indicating that the avalanche picked up more rock later in its formation (Fig. 8). Furthermore, the earlier lobes, as determined by their relative stratigraphic position, appear to be thinner than the rocky lobes. This evidence suggests that the earlier stages were more fluid, potentially due to a composition of predominantly ice or the presence of liquid water, in contrast with the rock-rich later lobes. The total maximum runout length of the avalanche was $4950 \mathrm{~m}$ with an elevation drop of $1650 \mathrm{~m}$. The deposit appears white from the failure zone to an elevation of $\sim 1600 \mathrm{~m}$, where it becomes significantly darker. This likely reflects a zone in which rock was entrained into the avalanche.

\section{SEISMIC DATA}

Due to the presence of a real-time seismic network on Iliamna for the purposes of volcanic monitoring, all of the avalanches since 1994 have been recorded seismically. These data show that such events exhibit characteristic seismic signatures that differ from other seismic signals commonly recorded on volcanoes. We next describe the seismic network and the signals recorded before and during the avalanches and relate them to avalanche failure and dynamics.

Iliamna has been seismically monitored by the Alaska Volcano Observatory since 1987, and since 1996 has had a network of six seismometers, as illustrated in Figure 1 (ILW, INE, etc.). All stations have short-period vertical instruments,
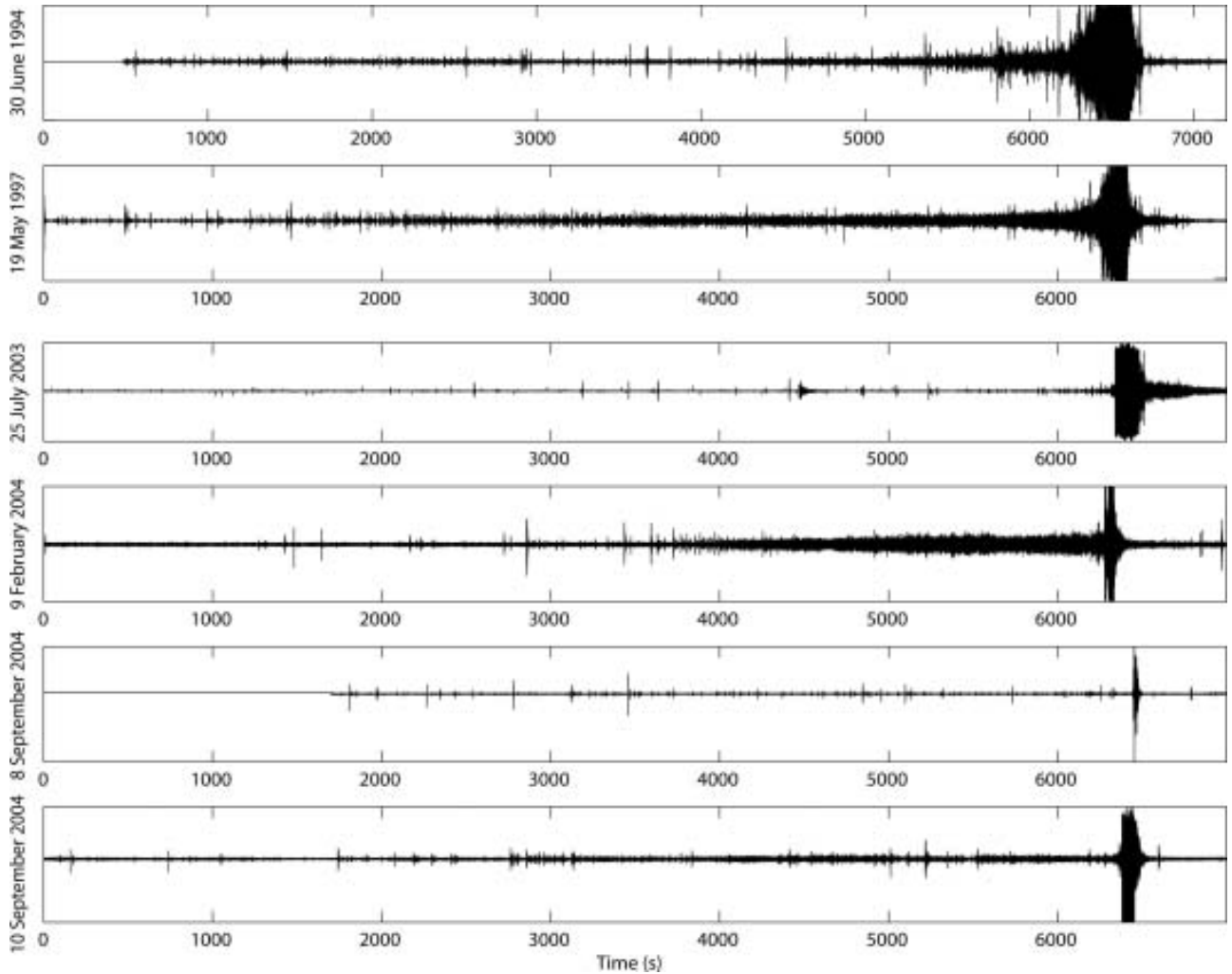

Fig. 9. Time series for the six major avalanches described here, each showing 2 hours of data. In each case, the sequence begins with a series of discrete earthquakes that are highly repetitive in time series. The discrete events occur with increasing frequency until they degrade into a continuous signal that gradually increases in amplitude. Each sequence culminates in a strong signal that saturates the nearest stations. The stations (see Fig. 1) from which data are plotted for each event are as follows: 30 June 1994, INE; 19 May 1997, IVE; 25 July 2003, ILI; 9 February 2004, INE; 8 September 2004, IVS; 10 September 2004, ILW. 


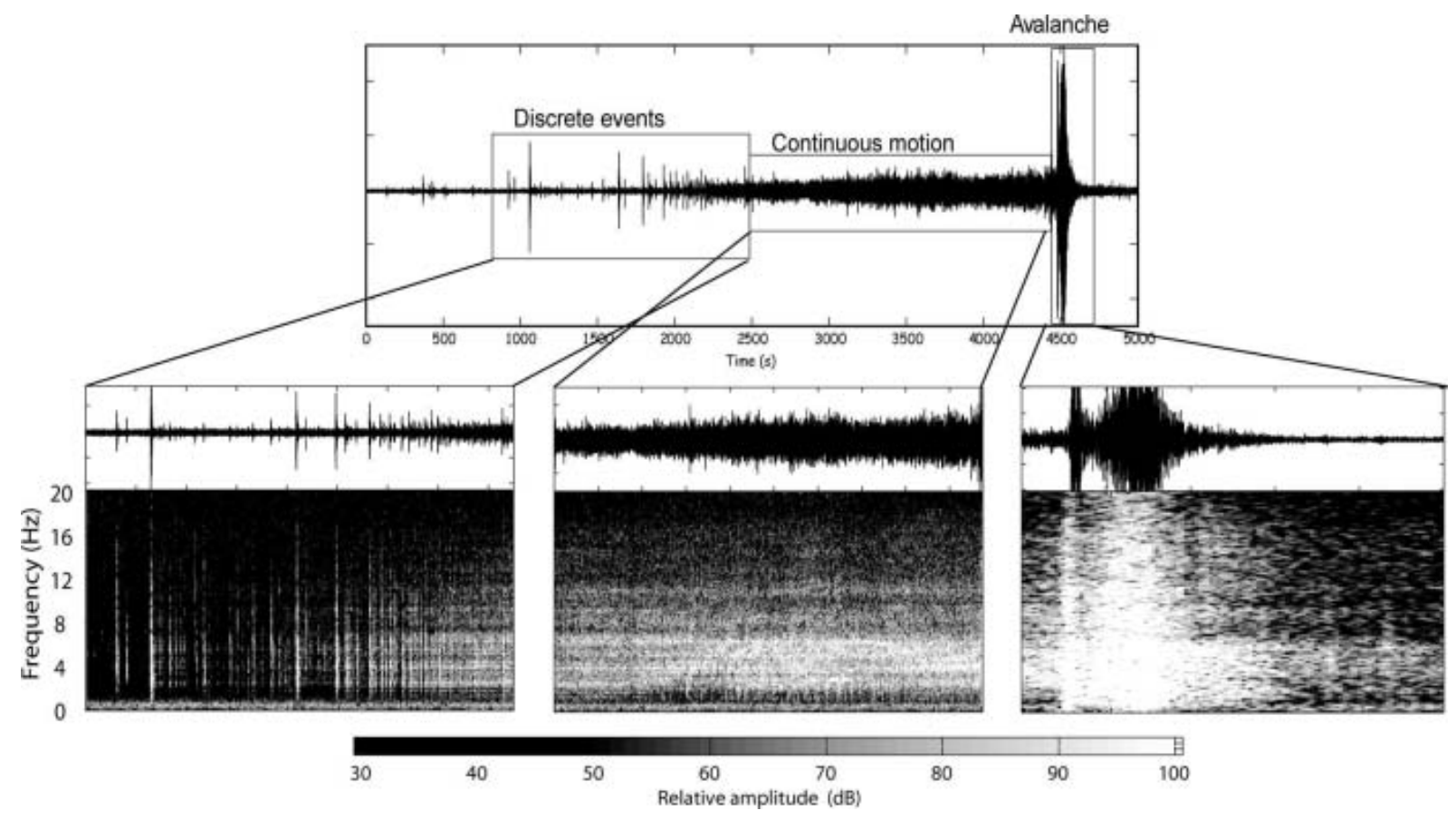

Fig. 10. Time series and spectrogram of the 10 September 2004 avalanche. Lighter tones represent frequencies with greatest amplitude. The three sub-phases of the avalanche signal are shown: the sequence of discrete events, the continuous ground-shaking and the avalanche.

and one station (IVE, Fig. 1) has a second instrument recording horizontal motion. The short-period nature of the seismometers means that signals are recorded most effectively at frequencies of $1-20 \mathrm{~Hz}$. Data are sent in real time by radio and telephone line to the Alaska Volcano Observatory where they are digitized at $100 \mathrm{~Hz}$.

All of the avalanches described here were recorded by the Iliamna seismic network (Fig. 9). At the time of the 1994 event, only a single station was operational on Iliamna, making detailed analysis of that event impossible. The 1997, 2003 and 2004 events were all recorded on at least four stations. In some cases, stations were adversely affected by noise from weather or telemetry.

\section{SEISMIC SIGNAL ANALYSIS}

Seismic signals from rockfalls, avalanches and landslides have a characteristic signal defined by a 'spindle shape' in time series, and a broadband $(1-20 \mathrm{~Hz})$ spectral content (Norris, 1994; Kishimura and Izumi, 1997; Caplan-Auerbach and others, 2001; Suriñach and others, 2001). High signal amplitude is thought to represent times when the avalanche changed path, either through a turn in its path or a change in slope, thereby transmitting more energy into the ground (Suriñach and others, 2001), although signal amplitude may also be affected by motion towards or away from a given seismometer (Suriñach and others, 2005). Signal amplitude may also be affected by variations in surface roughness or basal shear stress, resulting in changes in both avalanche velocity and seismic coupling (Röthlisberger, 1987). Rockfall and avalanche signals may comprise several pulses of energy, reflecting one of the effects described above, or the occurrence of multiple failures.

Iliamna avalanches are unusual in that they exhibit a precursory seismic sequence prior to failure (Caplan-Auerbach and others, 2004). Precursory seismic signals are observed up to 2 hours prior to the spindle-shaped avalanche signal
(Fig. 9). This signal is observed only in those avalanches believed to initiate in ice. Snow avalanches and debris avalanches initiating in rock do not exhibit any precursory seismicity (Norris, 1994; Suriñach and others, 2001).

The precursory portion of Iliamna avalanche seismicity follows a predictable pattern composed of three sub-phases (Fig. 10). All the signals initiate with a sequence of discrete earthquakes that are highly repetitive in time series. These events occur more and more frequently until the signal degrades into a continuous ground-shaking that gradually increases in amplitude. These two signals were first described by Caplan-Auerbach and others (2004) and are believed to represent precursory seismicity immediately prior to avalanche failure. The continuous ground-shaking culminates in a strong, broadband signal believed to represent the actual avalanche.

We begin by discussing the period of discrete earthquakes. These earthquakes are fairly low-frequency, with spectral peaks near $1-8 \mathrm{~Hz}$. The number of earthquakes locating in the immediate avalanche area in the 2 hours preceding the event ranges from $\sim 40$ to 100 , with earthquakes becoming progressively more frequent with time. The low number of seismic stations as well as the low amplitude $(<M 1)$ and emergent onset of the earthquakes makes it difficult to precisely constrain hypocenters using standard location techniques. However, the fact that the earthquakes are similar allows us to stack the data, thereby enhancing signal-to-noise ratios and illuminating the P-wave onset. We then cross-correlate each earthquake with the stacked event to estimate the P-wave timing for that event. Using this method to time and locate the events, earthquakes are found to cluster near the presumed headwall of their associated avalanche (Fig. 1). This is a strong indicator that these events are associated with the avalanche failure zone and are not coincidental.

As the sequence progresses, the discrete quakes occur more and more frequently until the signal degrades into 


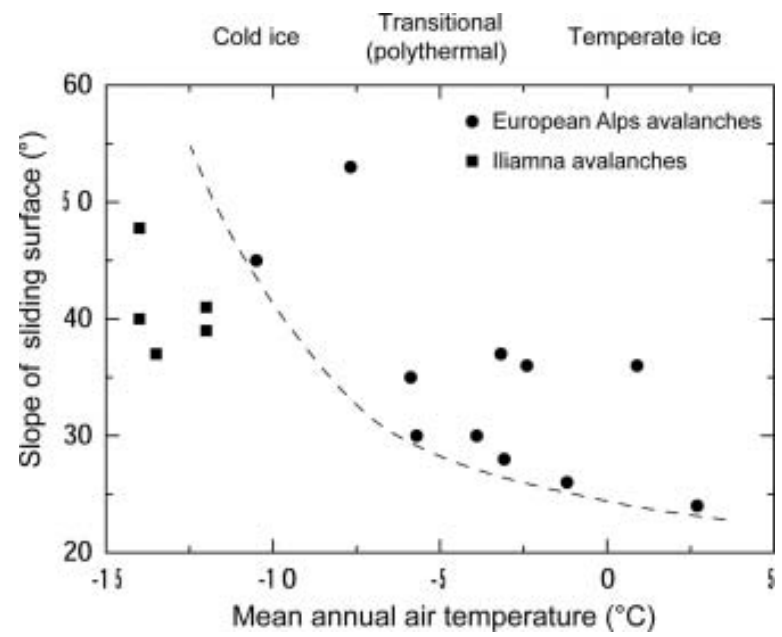

Fig. 11. Relation between mean annual air temperature (MAAT) at the ice avalanche starting zone and critical slope of the failure. Data from the European Alps are from Huggel and others (2004). The dashed line indicates a possible boundary condition for the relationship between MAAT and sliding slope as estimated for the European events.

continuous ground-shaking (Fig. 10). Continuous signals cannot be located using conventional seismic methods. Instead, we evaluate the power spectrum of the signal, to see if this provides insight into the source of the continuous signal. While the power spectrum is not a sufficient means by which the source mechanism can be positively identified, events with similar source processes located in the same area will exhibit similar power spectra. The fact that the spectral content of the discrete earthquakes and the continuous signal are similar, suggests that in this second phase the earthquakes have simply begun to overlap in time and that the continuous signal occurs in the same location as the quakes. As the continuous signal progresses, the spectral content evolves to a broader-band spectrum. This indicates a gradual change in either the source process or source location.

In each event, the seismic sequence culminates with a strong broadband $(1-20 \mathrm{~Hz})$ signal that saturates the nearest stations $(<10 \mathrm{~km}$; Figs 9 and 10$)$. In some cases, this portion of the signal was weakly recorded as far away as Augustine volcano, $\sim 100 \mathrm{~km}$ from Iliamna. In several cases, notably the July 2003 and the two September 2004 events, this portion of the signal is composed of at least two pulses of energy, each of which has a gradual onset and decline in a so-called spindle shape. The spectral content and spindle shapes are characteristic of mass-wasting events, indicating that this part of the signal represents the actual downslope motion of the avalanche. The duration of this portion of the signal (based on the timing of periods of significant amplitude increase and decrease) varies from $\sim 40$ to $500 \mathrm{~s}$ and roughly correlates with avalanche volume (Table 1). This could be due to conditions in which a large amount of material is progressively added to the avalanche, increasing signal duration. Alternatively it could simply reflect the fact that a larger amount of material exerts a stronger force upon the ground and might generate a strong signal-to-noise ratio for a longer time. The observed trend contrasts with observations by Tilling and others (1975), indicating poor correlation between volume and duration for rockfall signals on Kilauea volcano, Hawaii, USA. Norris (1994) found that avalanche volume correlates with signal amplitude for events occurring in the Cascades, but saturation of seismic signals precludes our investigating this relationship on Iliamna.

\section{GLACIOLOGICAL SIGNIFICANCE}

\section{Failure preconditions}

The avalanche release zones at Iliamna volcano all show similar slab failures, also referred to as ramp failures. All of them originated from more-or-less intact ice near the bergschrund and involved major volumes of ice, except for the 8 September 2004 avalanche which was likely related to debuttressing. The 30 June 1994 and 10 September 2004 events were released along an almost perfectly uniformly inclined slope, i.e. classical ramp failures. Ice avalanche research separates failures into cliff-type and ramp-type categories (Haefeli, 1966; Alean, 1985). While cliff-type glaciers are characterized by a marked break in slope of the bedrock and/or ice and do not show a particular dependence of failure on the average slope of the glacier, ramp-type failures have been related to the slope of the initial starting zone (Alean, 1985; Huggel and others, 2004). Cliff failures may occur on Iliamna, but are less likely to be recorded seismically. Crevasse opening is thought to generate very small earthquakes (Métaxian and others, 2003), and the fact that the failure occurs in an isolated ice wedge makes the energy less likely to couple into the rocky edifice. Consequently, the seismic energy generated in a wedge failure probably attenuates rapidly.

The slope of ramp-failure zones usually shows a dependence on ice temperature. In the absence of direct measurements, the firn temperature can be used to estimate the mean annual air temperature (MAAT) at the given elevation. For steep glaciers with comparably small ice thickness (here about $10-50 \mathrm{~m}$ ) the temperature at the glacier bed can be reasonably approximated by the firn temperature (Huggel and others, 2004). It should be noted, however, that these relationships are non-linear. In the case of Iliamna volcano, the closest meteorological stations are located in the towns of Iliamna (50 ma.m.s.l.) and Homer (sea level), $100 \mathrm{~km}$ southwest and $90 \mathrm{~km}$ southeast of Iliamna volcano, respectively. The MAATs of $1^{\circ} \mathrm{C}$ for the town of Iliamna and $3{ }^{\circ} \mathrm{C}$ for Homer allow an extrapolation of the MAAT of $-11^{\circ} \mathrm{C}$ to $-15^{\circ} \mathrm{C}$ at the avalanche failure zones between 2200 and $2500 \mathrm{ma}$ a.m.s.l. If conditions at the glacier base are controlled by air temperature, these estimated MAATs strongly suggest cold ice conditions at the base of the glaciers that have failed. However, while Iliamna has not erupted in historic time, it has an active fumarolic system and experienced a magmatic intrusion in 1996 (Roman and others, 2004). This points to a strong likelihood that Iliamna's glaciers are affected by internal heat. In Figure 11, MAAT vs failure slope data of the Iliamna avalanches are plotted with corresponding information from ice avalanches in the European Alps. The data suggest that the Iliamna avalanches fail at lower slopes at given ice temperatures (MAAT) than those observed in Alpine areas. Iliamna avalanches mostly fall below the $45^{\circ}$ slope threshold that is broadly assumed to be a minimum slope for failure in cold ice conditions (Alean, 1985; Huggel and others, 2004). More data are undoubtedly needed, but the question arises as to whether the $45^{\circ}$ slope assumption needs to be revised or whether Iliamna's status 
as an active volcano yields conditions resulting in low-slope failures. This may also explain the unusually high frequency of major ice avalanches at Iliamna.

\section{Failure trigger}

To gain a better insight into avalanching at Iliamna, and to investigate the likelihood that seismic data could be used to provide warning prior to avalanches, the failure conditions and mechanisms are investigated here in more detail.

All ice avalanches observed in the past from Iliamna originated from the eastern side of the volcano within hydrothermally altered rock. The effect of strongly weakened rock with respect to avalanching may be twofold. A failure may occur in the bedrock underlying the ice entraining a portion of glacier ice, thus resulting in an ice-rock avalanche. Alternatively, failure may occur within the ice or at the glacial base, and the subsequent avalanche may entrain friable rock. Observations indicate that the 25 July 2003 avalanche contained a significant amount of rock, but it is uncertain whether the failure actually occurred in the bedrock (Fig. 4). However, both major 2004 avalanches, on 9 February and 10 September, were clearly failures within ice, and the 1994 and 1997 headwalls are suggestive of removal of ice to the underlying bedrock (Fig. 2). The effect of altered rock may then have been more through a reduction of cohesion at the ice-rock interface and hence a reduction in basal shear strength. Fractured rock can provide a conduit through which volcanic gases can escape the edifice and impact upon the base of the glacier, promoting melting and instability. Unstable rock can also produce rockfalls and trigger a failure of the ice by impact force or repeated loading on the surface which leads to an increase of normal and shear stress at the base of the glacier (Huggel and others, 2005). Still, neither visual observations nor satellite image analysis or seismic signals provide an indication of rockfall-induced ice avalanches for those events with precursory seismicity. In May 2005 a series of rockfalls with no precursory seismicity was recorded at Iliamna. Photographs of those events show that they were composed almost exclusively of rock, with little to no ice component (Caplan-Auerbach and others, 2004). This is yet another indication that the precursory seismicity is exclusive to ramp failures.

The avalanches on Red Glacier point to the occurrence of repeated failures from the same location. In fact, the 1994, 1997 and 2003 avalanches show virtually identical failure sites in terms of location and geometry (Figs 1 and 3). Failure cycles at small and steep glaciers were discussed by Post and La Chapelle (1971) and Röthlisberger (1987) as processes of mass build-up to a critical level where eventually failure occurs, i.e. accumulation leads to an increase of ice thickness until the proportionally growing shear stress overcomes shear strength. Observations document recent failure cycles of only 3-6years, an extraordinarily high periodicity that must be related to the high precipitation rates on Iliamna (> 2 m water equivalent; Jones and Fahl, 1994).

Ice temperature estimates show that the ice should be frozen to the bedrock in the avalanche initiation zone. After failure the uncovered bedrock is directly exposed to (cold) atmospheric temperatures. Subsequent firn accumulation then increases the temperature at the previously exposed surface. Such thermal disturbances contribute to instabilities at the ice-rock interface (Haeberli and others, 2004). If we consider the existence of water at the glacier bed, however,

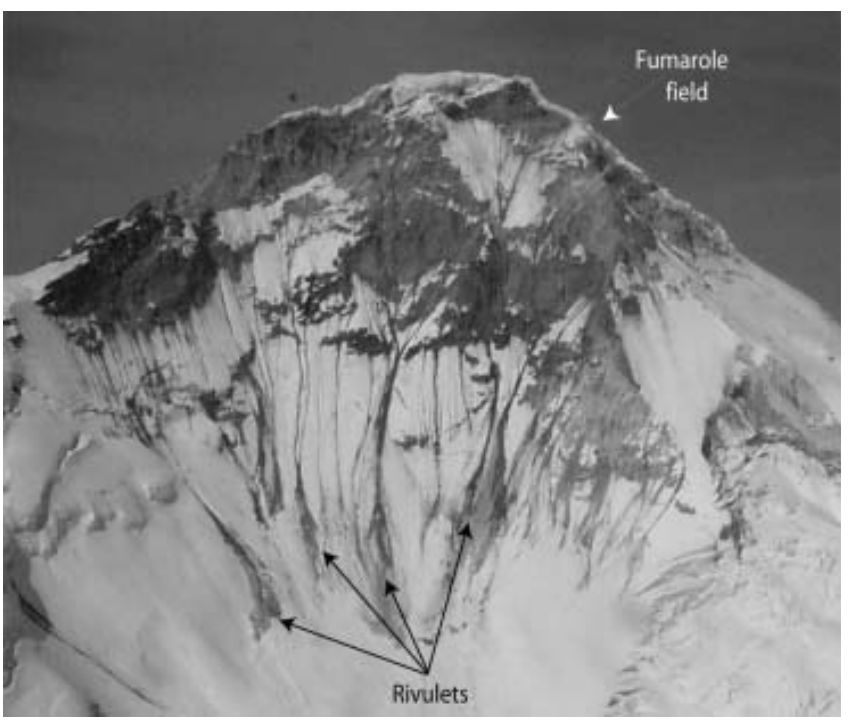

Fig. 12. Evidence of water on the eastern flank of Iliamna, taken in August 2004. Small rivulets are flowing down the top part of the eastern flank. The main fumarole field is visible, weakly steaming in the upper part of the photo. Look angle is to the west. Photo by M. Doukas, US Geological Survey.

conditions change significantly relative to pure cold-ice conditions. In fact, there is evidence of water in the headwall region according to photographs that show water sources and small debris flows along the eastern flank of Iliamna (Fig. 12). The presence of nearby fumaroles suggests the water may have a geothermal origin. Underneath the glacier, water increases the pore pressure, resulting in a reduction of normal stress and shear strength (Huggel and others, 2005). In fact, the occurrence of geothermally related water could likely be an explanation for the failures on less steep slopes for cold ice conditions. Similar phenomena were proposed for the enormous ice avalanche on Kolka glacier, Russian Caucasus, in 2002 (Haeberli and others, 2004; Huggel and others, 2005).

\section{Failure evolution}

The precursory seismic sequence observed prior to Iliamna avalanches has been interpreted as failure at the base of the glacier, within an ice layer, or within the punky rock at the ice-rock interface (Caplan-Auerbach and others, 2004). Opening-mode fracture at the headwall was deemed an unlikely cause of the precursory seismicity because the slip area is small, and seismicity associated with crevassing is consequently very weak (Blankenship and others, 1987; Anandakrishnan and Bentley, 1993; Métaxian and others, 2003). In their seminal study of glacial icequakes associated with crevassing, Neave and Savage (1970) estimated that a typical icequake releases $\sim 1 \mathrm{~J}$ of energy. The precursory earthquakes at Iliamna have magnitudes in the $\sim 0.5-1$ range, which would have an expected energy release of $\sim 10^{5}-10^{6} \mathrm{~J}$. This is the size described by Weaver and Malone (1979) for quakes associated with incremental basal slip on glaciers in the Cascades. Consequently, this precursory seismicity may be exclusive to ice avalanches exhibiting ramp as opposed to cliff or wedge failure. Presumably the ice begins to slip in discrete lurches which become more frequent as failure progresses. Ideally this could be confirmed using earthquake focal mechanisms; slip on the glacier base should be 
identifiable as normal faulting along a predictable strike (that of the flank). Unfortunately it is impossible to calculate earthquake focal mechanisms for these events due to the small number of instruments in Iliamna's seismic network.

As previously noted, we interpret the continuous signal as due to the occurrence of many overlapping earthquakes, as the base of the ice continues to slide. At this stage the glacial motion is accommodated by deformation at the base (e.g. Iverson and Iverson, 2001). This failure progresses until the ice is no longer able to sustain the deformation, and the entire ice body fails. Downslope propagation is represented by the spindle-shaped signal.

From seismic data analysis and visual observations, we argue that the failure process is as follows:

1. Crevasse opening. This process may be initiated months before failure and is characterized by continuous widening of the crack. Slip movement at the base of the glacier is still slow and limited in space at this early stage, but crevasse formation can provide meltwater access to the basal ice. Seismic signals associated with crevassing are likely to be small, due to the small slip area, and may not be locatable (Métaxian and others, 2003).

2. Spreading and acceleration of glacier movement. This phase, occurring days (and possibly weeks) before failure, is not directly evidenced by seismic data, due to insufficient magnitude and long duration. Ice velocity measurements performed at the front of steep cliff-type and calving glaciers showed an exponential acceleration of the movement before failure by crack formation and ice block rotation (Haeberli and Röthlisberger, 1976; Flotron, 1977; Iken, 1977; Lüthi, 2003; Pralong and others, 2003; Wegmann and others, 2003). Although these measurements cannot directly be transferred to conditions of a constantly inclined slope as found on Iliamna, the observed fractures (Fig. 7) suggest a similar type of acceleration. The onset of phase (ii) may be related to the existence of water at the base of the glacier.

3. Discrete slipping. Roughly 2 hours before failure, the ice movement process starts to be captured by seismic sensors, and is thought to represent discrete slip events at the glacier base. The magnitude of these events is small (<M1) suggesting that the glacier only slips a small amount ( $1 \mathrm{~cm}$; Weaver and Malone, 1979) during each earthquake.

4. Continuous slipping. The discrete movement transforms into a continuous process about $0.5-1$ hour before failure. Although not always evidenced in seismic data, it is reasonable to assume an acceleration of the movement, as reported by velocity measurements (Flotron, 1977; Röthlisberger, 1977). Because slip occurs for a prolonged period of time during this phase, it is probably accommodated by deformation along the glacier base (Iverson and Iverson, 2001).

\section{Avalanche velocities}

The broadband, spindle-shaped seismic signal recorded in association with Iliamna avalanches is thought to represent the downslope transport of ice and rock. The duration of this signal, combined with observed avalanche runout distances can therefore help constrain avalanche velocities. We estimate avalanche velocities by low-pass filtering the seismic record and measuring the period in which the seismic envelope exhibits a strong amplitude increase. However, the actual start and end times of the avalanche are poorly constrained, so these durations may be off by as much as $10-20 \%$. Furthermore, the seismic record indicates the total period of ground-shaking rather than the time that a single mass moved downslope. We cannot distinguish between multiple failures in a single avalanche, nor can we identify how far a given lobe of material moved. It is likely that some material was entrained along the way, so the runout distance for an individual particle is likely to be less than the total value presented here. As a consequence, velocities are maximum values, assuming that material covers the entire length of the observed runout. In actuality, avalanches undergo a period of acceleration as the ice initially fails, followed by a period in which the velocity is largely controlled by topography. This may account for the multiple pulses of energy exhibited in the seismic signal. Alternatively, these pulses may represent multiple failures, or they may reflect an acceleration of the avalanche, either by a change in slope, a change in the direction of travel or a change in path roughness or material property.

Iliamna avalanche velocities are found to be $20-77 \mathrm{~m} \mathrm{~s}^{-1}$ (Table 1), with an average of $\sim 46 \mathrm{~m} \mathrm{~s}^{-1}$. This value is consistent with velocities proposed for other snow, ice and rock avalanches. For example, ice avalanches in Tibet were estimated to have traveled at $21-35 \mathrm{~m} \mathrm{~s}^{-1}$ (Van der Woerd and others, 2004), and snow velocities have been found to have velocities in the range of $25-57 \mathrm{~m} \mathrm{~s}^{-1}$ (Kishimura and Izumi, 1997). The avalanche from Kolka glacier is estimated to have moved at maximum velocities of $50-80 \mathrm{~m} \mathrm{~s}^{-1}$ (Huggel and others, 2005), while debris flows on volcanoes are found to have velocities of up to $25-40 \mathrm{~m} \mathrm{~s}^{-1}$ (Pierson, 1995; Scott and others, 1995). We also note that the fastest Iliamna avalanche is the February 2004 event, the only one composed exclusively of snow and ice.

\section{Avalanche runout and forecast}

The runout length of the avalanche is a determinant element for hazards assessment by defining the approximate area likely to be affected. Ice avalanche studies in the European Alps have found a minimum drop height to runout length ratio $(H / L)$ of 0.31 for avalanche volumes of up to $\sim 10^{6} \mathrm{~m}^{3}$ (Alean, 1985; Huggel and others, 2004). Large events such as the 1970 Huascarán or the 2002 Caucasus avalanche have under-run this value but involved flow transformation into more liquid and debris-laden flows. The avalanches observed on Iliamna, however, did not show similar flow transformation phenomena and thus suggest that also pure ice avalanches can have $H / L$ ratios as low as 0.18 (Table 1 ). While these values differ from those in the European Alps, low $H / L$ ratios are not uncommon for volcanic landslides or debris avalanches (Waythomas and others, 2000; Legros, 2002). An approach for a better understanding of the low $H / L$ ratios may consider the avalanche volume. A considerable number of empirical relationships have been proposed that relate $H / L$ to the volume of different types of ice and rock avalanches, landslides or debris flows (e.g. Evans and Clague, 1988; Corominas, 1996; Legros, 2002; Huggel and others, 2004). Large ice avalanches could produce more frictional melting at the avalanche base and promote fluidization effects. In an extreme case, if the fluid pressure gradient becomes equal to lithostatic, solid friction can decrease to zero. In the case of Iliamna avalanches, the characteristics of the avalanche trajectory are another factor 
likely contributing to a long runout. First, the cone-shaped morphology of the volcano puts few topographic constraints on runout. Second, the large ice cover on Iliamna implies that all observed avalanches travel mostly on glacier ice and snow. Friction can thus be significantly reduced in comparison to the typically rougher surface beyond the glacier extent.

Acquiring a better understanding of avalanche dynamics is helpful for modeling purposes and eventually for hazard assessment and mapping, as well as quantifying parameters associated with ice dynamics immediately prior to and during a failure event. However, the seismic data collected at Iliamna also suggest the possibility of a short-term warning system. The first identifiable phase of avalanche failure is the period of discrete earthquakes. Because this signal occurs up to 2 hours prior to the actual avalanche, it provides a means of short-term avalanche forecasting. Although seismicity is common in volcanic and ice-covered terrain, the signal associated with Iliamna ice avalanches is unique and easily distinguishable from other volcanoseismic processes. Specifically, glacial failure may be identified by the repetitive nature of these events in combination with the rapid increase in event occurrence rate. Similar signals have not been observed on Iliamna in the absence of an avalanche. The period of continuous ground-shaking, while not strongly observed in every avalanche, is another telltale sign of impending failure. Our hope is that a more detailed study of these precursory signals, including rapid hypo-central locations, seismic focal mechanisms and estimates of source volume, will provide information to develop a warning system for similar future events. To actually accomplish this, several practical and technical challenges must be overcome, such as rapid signal processing and event location, reliability checks prior to the issuing of warnings and correlation of seismic parameters with estimates of avalanche volume. Further analysis of the features characteristic of ice avalanching (e.g. the increase in event occurrence rate and the gradual transition to a continuous signal) is required to determine which parameters could be best used in an alarm algorithm. These procedures are currently not yet operational.

\section{CONCLUSIONS}

Ice avalanches present a hazard to high-mountain communities, but their infrequent occurrence renders them understudied. Furthermore, such events are typically studied only after they have occurred, so there is no means by which failure and propagation may be investigated as they happen. The high frequency and high magnitude of Iliamna ice avalanches make it an excellent laboratory for the study of these events and for advancing our understanding in terms of avalanche trigger, failure and dynamics. Specifically, the analysis of Iliamna avalanche dynamics can foster the application and verification of dynamic avalanche models. We therefore provide important parameters including initial failure volume, entrainment, velocities and travel distances. Although no serious hazards emerge from these avalanches due to the remoteness of Iliamna, the study of the avalanche can improve hazard assessments at locations with similar conditions but much higher damage potential such as the Cascades or the European Alps. The short-period seismic data recorded in concert with Iliamna avalanches suggest there is a characteristic precursory seismic sequence that may one day provide warning in advance of avalanche failure. It is difficult to precisely identify the failure mechanisms. However, seismic signals suggest that Iliamna avalanches fail along the glacier base; discrete earthquakes on the base degrade into continuous slip for up to several hours before the glacier gives way. Glacial failure may begin up to several weeks prior to this point, but is not detected by seismometers. The majority of Iliamna events occur in the spring or summer, suggesting that they are triggered by increases in meltwater along the glacial base, possibly promoted by crevasse opening at the headwall. It is likely that increases in heat or fumarolic activity resulting from volcanic unrest, as well as stress build-up and warming of basal layers by reformation of firn, promote avalanching and glacial failure. Precursory seismic signals recorded across the local network may be exclusive to ramp failures, as opposed to cliff or wedge failures. This is due to the larger slip area as well as enhanced seismic coupling with the edifice relative to seismic signals associated with crevassing.

The goal of predicting avalanche failure and mitigating the associated hazards still requires a considerable amount of work. Understanding the timing and volume of the initial failure could benefit from moment tensor analyses, for which we require dense broadband seismic data. Such data would also prove useful in examining an empirical relationship between avalanche volume and seismic signal amplitude for rapid estimation of avalanche size.

\section{ACKNOWLEDGEMENTS}

These studies were partly funded by the US Geological Survey's Mendenhall Postdoctoral Program, and by the Swiss National Science Foundation. We thank P. Bartelt and two anonymous reviewers for helpful and constructive comments, the Alaska Volcano Observatory for their support, C. Waythomas and R. Wessels for discussions that improved this manuscript, W. Haeberli and colleagues at the University of Zürich for critically commenting on the manuscript, and J. Alean for generously providing information on Iliamna avalanches.

\section{REFERENCES}

Alean, J. 1984. Untersuchungen über Entstehungsbedingungen und Reichweiten von Eislawinen. VAWE Mitt. 74.

Alean, J. 1985. Ice avalanches: some empirical information about their formation and reach. J. Glaciol., 31(109), 324-333.

Anandakrishnan, S. and C.R. Bentley. 1993. Micro-earthquakes beneath Ice Streams B and C, West Antarctica: observations and implications. J. Glaciol., 39(133), 455-462.

Blankenship, D.D., S. Anandakrishnan, J.L. Kempf and C.R. Bentley. 1987. Microearthquakes under and alongside Ice Stream B, Antarctica, detected by a new passive seismic array. Ann. Glaciol., 9, 30-34.

Caplan-Auerbach, J., C.G. Fox and F.K. Duennebier. 2001. Hydroacoustic detection of submarine landslides on Kilauea volcano. Geophys. Res. Lett., 28(9), 1811-1814.

Caplan-Auerbach, J., S.G. Prejean and J.A. Power. 2004. Seismic signals associated with ice and debris avalanches at Iliamna volcano, Alaska. Acta Vulcanol., 16(1-2), 9-20.

Corominas, J. 1996. The angle of reach as a mobility index for small and large landslides. Can. Geotech. J., 33(2), 260-271.

Detterman, R.L. and J.K. Hartsock, 1966. Geology of IniskinTuxedni region, Alaska. USGS Prof. Pap., 512. 
Evans, S.G. and J.J. Clague. 1988. Catastrophic rock avalanches in glacial environments. In Bonnard, C., ed. Landslides: Proceedings of the 5th International Symposium on Landslides, 1015 July 1988, Lausanne, Switzerland. Rotterdam, A.A. Balkema, $1153-1158$.

Flotron, A. 1977. Movement studies on a hanging glacier in relation with an ice avalanche. J. Glaciol., 19(81), 671-672.

Haeberli, W. 2005. Investigating glacier-permafrost relationships in high-mountain areas: historical background, selected examples and research needs. In Harris, C. and J.B. Murton, eds. Cryospheric systems: glaciers and permafrost. London, Geological Society of London, 29-37. (Special publication 242.)

Haeberli, W. and H. Röthlisberger. 1976. Beobachtungen zum Mechanismus und zu den Auswirkungen von Kalbungen am Grubengletscher (Saastal, Schweiz). Z. Gletscherkd. Glazialgeol., 11(2), 221-228.

Haeberli, W., J.C. Alean, P. Müller and M. Funk. 1989. Assessing risks from glacier hazards in high mountain regions: some experiences in the Swiss Alps. Ann. Glaciol., 13, 96-102.

Haeberli, W. and 7 others. 2004. The Kolka-Karmadon rock/ice slide of 20 September 2002: an extraordinary event of historical dimensions in North Ossetia, Russian Caucasus. J. Glaciol., 50(171), 533-546.

Haefeli, R. 1966. Note sur la classification, le mécanisme et le contrôle des avalanches de glaces et des crues glaciaires extraordinaires. IASH Publ. 69 (Symposium at Davos 1965 Scientific Aspects of Snow and Ice Avalanches), 316-325.

Huggel, C., W. Haeberli, A. Kääb, D. Bieri and S. Richardson. 2004. An assessment procedure for glacial hazards in the Swiss Alps. Can. Geotech. J., 41(6), 1068-1083.

Huggel, C. and 6 others. 2005. The 2002 rock/ice avalanche at Kolka/Karmadon, Russian Caucasus: assessment of extraordinary avalanche formation and mobility, and application of QuickBird satellite imagery. Natur. Hazards Earth Syst. Sci. (NHESS), 5(2), 173-187.

Iken, A. 1977. Movement of a large ice mass before breaking off. J. Glaciol., 19(81), 595-605.

Iverson, N.R. and R.M. Iverson. 2001. Distributed shear of subglacial till due to Coulomb slip. J. Glaciol., 47(158), 481-488.

Jones, S.H. and C.B. Fahl. 1994. Magnitude and frequency of floods in Alaska and conterminous basins of Canada. USGS WaterResour. Invest. Rep., 93-4179.

Kääb, A., J.M. Reynolds and W. Haeberli. 2005. Glacier and permafrost hazards in high mountains. In Huber, U.M., H.K.M. Bugmann and M.A. Reasoner, eds. Global change and mountain regions: an overview of current knowledge. Dordrecht, Kluwer Academic Publishers, 225-234. (Advances in Global Change Research 23.)

Kishimura, K. and K. Izumi. 1997. Seismic signals induced by snow avalanche flow. Natur. Hazards, 15, 89-100.

Legros, F. 2002. The mobility of long-runout landslides. Eng. Geol., 63(3-4), 301-331.

Lüthi, M.P. 2003. Instability in glacial systems. In Funk, M., ed. Milestones in physical glaciology: from the pioneers to a modern science. VAW Mitt. 180, 63-70.

Margreth, S. and M. Funk. 1999. Hazard mapping for ice and combined snow/ice avalanches: two case studies from the Swiss and Italian Alps. Cold Reg. Sci. Technol., 30(1-3), 159-173.

Métaxian, J.-P., S. Araujo, M. Mora and P. Lesage. 2003. Seismicity related to the glacier of Cotopaxi Volcano, Ecuador. Geophys. Res. Lett., 30(9), 1483. (10.1029/2002GL016773.)

Neave, K.G. and J.C. Savage. 1970. Icequakes on the Athabasca Glacier. J. Geophys. Res., 75(8), 1351-1362.
Norris, R.D. 1994. Seismicity of rockfalls and avalanches at three cascade range volcanoes: implications for seismic detection of hazardous mass movements. Bull. Seismol. Soc. Am., 84(6), 1925-1939.

Pierson, T.C. 1995. Flow characteristics of large eruption-triggered debris flows at snow-clad volcanoes: constraints for debris-flow models. J. Volcan. Geotherm. Res., 66(1-4), 283-294.

Plafker, G. and F.E. Ericksen. 1978. Nevados Huascarán avalanches, Peru. In Voight, B., ed. Rockslides and avalanches, 1; Natural phenomena. Amsterdam, Elsevier, 277-314.

Post, A. and E.R. La Chapelle. 1971. Glacier ice. Seattle, WA, The Mountaineers and University of Washington Press.

Pralong, A., M. Funk and M.P. Lüthi. 2003. A description of crevasse formation using continuum damage mechanics. Ann. Glaciol., 37, 77-82.

Rabus, B., M. Eineder, A. Roth and R. Bamler. 2003. The shuttle radar topography mission: a new class of digital elevation models acquired by spaceborne radar. ISPRS J. Photogramm. Rem. Sens., 57(4), 241-262.

Roman, D.C. and 6 others. 2004. Evidence for dike emplacement beneath Iliamna Volcano, Alaska in 1996. J. Volcan. Geotherm. Res., 130(3-4), 265-284.

Röthlisberger, H. 1977. Ice avalanches. J. Glaciol., 19(81), 669-671.

Röthlisberger, H. 1987. Sliding phenomena in a steep section of Balmhorngletscher, Switzerland. J. Geophys. Res., 92(B9), 8999-9014.

Salzmann, N., A. Kääb, C. Huggel, B. Allgöwer and W. Haeberli. 2004. Assessment of the hazard potential of ice avalanches using remote sensing and GIS-modelling. Nor. Geogr. Tidsskr., 58(2), 74-84.

Scott, K.M., P.T. Pringle and J.W. Vallance. 1995. Sedimentology, behavior, and hazards of debris flows at Mount Rainier, Washington. USGS Prof. Pap., 1547.

Suriñach, E., G. Furdada, F. Sabot, B. Biescas and J.M. Vilaplana. 2001. On the characterization of seismic signals generated by snow avalanches for monitoring purposes. Ann. Glaciol., 32, 268-274.

Suriñach, E., I. Vilajosana, G. Khazaradze, B. Biescas, G. Furdada and J.M. Vilaplana. 2005. Seismic detection and characterization of landslides and other mass movements. Natur. Hazards Earth Syst. Sci. (NHESS), 5(6), 791-798.

Tilling, R., R.Y. Koyanagi and R.T. Holcomb. 1975. Rockfall seismicity: correlation with field observations, Makaopuhi Crater, Kilauea Volcano, Hawaii. J. Res. US Geol. Surv., 3, 345-361.

Trabant, D. 1999. Perennial snow and ice volumes on Iliamna Volcano, Alaska, estimated with ice radar and volume modeling. USGS Water-Resour. Invest. Rep. 99-4176.

Van der Woerd, J. and 6 others. 2004. Giant, M8 earthquaketriggered ice avalanches in the eastern Kunlun Shan, northern Tibet: characteristics, nature and dynamics. Geol. Soc. Am. Bull., 116(3), 394-406.

Waythomas, C.F., T.P. Miller and J.E. Beget. 2000. Record of Late Holocene debris avalanches and lahars at Iliamna Volcano, Alaska. J. Volcan. Geotherm. Res., 104(1-4), 97-130.

Weaver, C.S. and S.D. Malone. 1979. Seismic evidence for discrete glacier motion at the rock-ice interface. J. Glaciol., 23(89), 171-184.

Wegmann, M., M. Funk, A. Flotron and H. Keusen. 2003. Movement studies to forecast the time of breaking off of ice and rock masses. In Zschau, J. and A. Küppers, eds. Early warning systems for natural disasters reduction. Berlin, Springer Verlag, 565-568. 